\title{
Prospects and challenges to guinea fowl (Numida meleagris) production in Nigeria
}

\begin{abstract}
Next to the domestic fowl, the guinea fowl is the most important poultry species in Nigeria in terms of number and acceptability. Most of the commercial poultry production is focused on the exotic chicken neglecting other indigenous poultry species. Very little research studies have been carried out on the guinea fowl and it has remained largely unimproved. The prospects accruable from and challenges to the production of this species were reviewed in this paper as enumerated by various researches. Some of the benefits of guinea fowl include its adaptability to diverse climatic conditions and suitability for back-yard rearing. It consumes various nonconventional feedstuffs and is tolerant to most poultry diseases. It yields high protein and low fat carcass unlike the chicken. Chief among the problems militating against the production of guinea fowl in Nigeria is the predominant free-range management system which is plagued by various challenges such as high keet mortality, theft, predation, poor feeding and disease prevalence. It was recommended that there is need to improve its management in terms of proper and adequate nutrition, efficient disease prevention and management, adequate housing as well as good management practices tailored to suit its natural behavior to ensure an optimum productivity in the guinea fowl enterprise.
\end{abstract}

Keywords: guinea fowl, challenges, production, prospects
Volume 3 Issue 3 - 2018

Victoria $N$ Ebegbulem

Department of Animal Science, University of Calabar, Nigeria

Correspondence: Victoria N Ebegbulem, Department of Animal Science, University of Calabar, Nigeria, Tel 23480644 73566,Email vicnneb@gmail.com

Received: April 14, 2018 | Published: May 02, 2018

\section{Introduction}

Though it originated from Africa, the guinea fowl is rapidly growing in population around the world. In Nigeria, it is second to the domestic fowl in terms of number and protein supply. ${ }^{1}$ Large numbers of guinea fowl exist in the wild in the guinea savanna region of Nigeria. Despite this large numbers, most of the commercial poultry production is focused on the exotic chicken neglecting our indigenous poultry species. Very little research studies have been carried out on the guinea fowl. Owing to constant population rise, it becomes necessary for us to look inwards and develop our indigenous stock which is more tolerant to the diseases affecting other poultry species. It has a greater ability to survive poor conditions of management than the exotic chicken. Agwunobi \& Ekpenyong ${ }^{2}$ in their assessment of the nutritive and economic value of the guinea fowl reported that the guinea fowl carcass excelled in nutritive quality, had more protein and ash, and less fat content than that of broiler birds. Oke et al. ${ }^{3}$ observed that despite the abundant potential and popularity of this bird, it has remained unimproved either as meat or egg laying bird in Nigeria.

Ikani \& Dafwang ${ }^{4}$ assert that there are over 50 million semidomesticated guinea fowl in Nigeria which constitute about 25 percent of the entire population of domestic poultry. The animal protein consumption in Nigeria falls below the FAO recommended quantity of 35 grammes per caput per day FAO. ${ }^{5}$ This shortfall in animal protein intake is more severe in the rural areas of Nigeria due to the high cost of animal products. Next to the local chicken, guinea fowl meat and eggs provide good sources of cheap protein to the rural populaces ${ }^{6-8}$ which serve as buffers to shortages of poultry products. There are no social taboos to the consumption guinea fowl meat and eggs in Nigeria. In Botswana, evidence of wide acceptance of the guinea fowl by the populace has been reported. ${ }^{9}$

\section{Prospects of guinea fowl production}

The guinea fowl, though originated from tropical West Africa, is adaptable to various climatic conditions, therefore is reared even in temperate countries. ${ }^{10}$ In Nigeria and most other parts of Africa, the guinea fowl are reared in the traditional free-range system., ${ }^{4,11-14}$ Freerange guinea fowl is an important resource for resource-poor rural people in developing countries. The indigenous guinea fowl breeds do not require elaborate, expensive housing. Scavenging and foraging are common practices in the free-range system of management. They feed on a wide range of flora and fauna, scavenging over a large area of land in search of food. ${ }^{14}$ Guinea fowl consume a large range of non-conventional feed not used in feeding chicken. This makes it the poultry of choice to the poor. It is also an ideal bird in an integrated crop-livestock farming system. ${ }^{13}$

The guinea fowl egg and meat are good sources of protein and income. Ikani \& Dafwang ${ }^{4}$ reported that in Nigeria guinea fowl eggs and meat command premium prices because of their gamey flavor. Their eggs have better storage qualities than chicken eggs, as a result of their thicker shells therefore they do not crack easily. Gono et al. ${ }^{14}$ and Moreki \& Radikara ${ }^{10}$ reported that guinea fowl command premium prices in Zimbabwe and Botswana respectively. The guinea fowl meat is reported Moreki \& Seabo ${ }^{9}$ to be high in protein and low in fat content, making it more desirable than chicken meat. The authors asserted that guinea fowl meat has a protein content of about 28 percent as against 20 percent in the domestic chicken. Agwunobi and Ekpenyong (1990) opined that meat of the guinea fowl is tastier and firmer than that of the chicken. The authors added that the yield of edible meat is also higher than that of the domestic chicken as a result of its slender skeleton. 
Guinea fowl play important socio-cultural roles in the lives many tribes. They are used for religious sacrifices and to perform some funeral rites. Their colorful feathers are used by local craftsmen for artworks and making of decorative articles. Guinea fowl has been reported to be tolerant to most poultry diseases..$^{10,14,15}$ Sayila ${ }^{12}$ reported that guinea fowl are resistant to most poultry diseases such as gumboro, Newcastle disease and salmonellosis. Besides, Bankoungou ${ }^{16}$ reported that the local guinea fowls are tolerant to common viral and bacterial diseases.

\section{Challenges to guinea fowl production}

Despite the abundant number of guinea fowls in Nigeria and its numerous benefits, the production of guinea fowl is still at a rudimentary level. The production of guinea fowl, unlike the domestic chicken is plagued by numerous challenges. According to Ocheja et al. ${ }^{17}$ full scale domestication of the guinea fowl has not been attempted in Nigeria because seemingly, little attention has been given to its commercial production as the prevailing situation is small flocks maintained in free range. The husbandry is restricted to the rural areas of the savanna zone of the country.

The free-range system of management is the common system of rearing guinea fowl in Nigeria and most other African countries. ${ }^{12}$ ${ }_{13,18,19}$ Moreki \& Radikara $^{10}$ noted that poor housing pose a serious challenge to guinea fowl rearing. Due to poor housing, predation rates are high. The author observed low egg productivity due to frequent change of laying spot in the bush leads to egg being preyed upon. This observation is in tandem with that of Kebede et al. ${ }^{21}$ and Gono et al. ${ }^{14}$ Predators such as snakes, wild cats, dogs, and hawks are a problem in the free-range system.

Presently in Nigeria there is no commercially compounded feed for guinea fowl. Birds are allowed to scavenge for most of their food around the village .This observation is in line with the report of Dahouda et al. ${ }^{5}$ who reported that guinea fowl keepers did not practice any rationale feeding system for their birds. Gono et al. ${ }^{14}$ observed that in addition to scavenging most of the farmers provided small amounts of supplementary feed to their birds. This is in agreement with the report of Kusina et al. ${ }^{13}$ who noted that feed was given to birds in an haphazard manner. Lack of information about feed requirements contributed to early keet mortality, besides, a large percentage of farmers were compelled to keep the birds on free range because they did not know their nutrient requirements, the authors concluded. Moreki \& Seabo ${ }^{14}$ observed that because there were no formulated rations for domesticated guinea fowl, farmers resorted to feeding their guinea fowls with commercial broiler chicken and layer chicken diets, with cereal grains and green vegetables as supplementary feeds. Dahouda et al. ${ }^{11}$ however noted that there was more feed available for poultry after harvesting from December to February but that this supplementation was sub-optimal and could not meet the bird's nutrient requirements. Inadequate feed supplies give rise to poor growth rates, low egg production and increased mortalities. ${ }^{10}$

Though resistant to most poultry diseases, the guinea fowl however suffer from some diseases of poultry. Bankoungou ${ }^{16}$ reported that guinea fowls are intolerant to internal and external parasites as a result of their scavenging behavior under the free-range system of management. This report is in line with the report of Dahouda et al. ${ }^{11}$ in Benin which showed that high keet mortalities were as a result of parasitic infections. Boko et al. ${ }^{21}$ identified the diseases of guinea fowl to include collibacilosis, salmonellosis and Newcastle disease. Teye $\& \mathrm{Gyawu}^{15}$ reported that in Ghana, guinea fowls though resistant to common avian diseases suffered from yolk sac infection, leg paralysis and worm infestation. The authors identified leg paralysis as a major cause of mortality and stunted growth attributed it to inadequate nutrition and absence of marek's disease vaccination. Ebegbulem ${ }^{22}$ noted that leg paralysis between the ages of 2-5 weeks and the resultant inability of the affected birds to feed, led to loss of considerable number of keets. Moreki et al. ${ }^{23}$ listed the common diseases of guinea fowl in Botswana in order of prevalence to be Coccidiosis, helminthiasis, colisepticaemia, salmonellosis, trauma, pediculosis and hardware disease. Moreki \& Radikara ${ }^{10}$ observed that rural farmers often used ethno-veterinary medicine as a substitute for conventional veterinary support. High keet mortality has been reported by several authors as a major constraint to guinea fowl production. ${ }^{24,6,14}$ Dahouda et al. ${ }^{11}$ observed that guinea fowl productivity is low because of high keet mortality. The authors recorded an average keet mortality of 74 percent within the first month of age. The mortality was attributed to the exposure of the keets to bad weather such as rain, cold or heavy dew and probably also due to parasites. According to Boko et al. ${ }^{21}$ thermoregulation system in young guinea fowl is not very efficient during the first month of life; as a result young keets are very sensitive to the differences between day and night temperatures during the rainy season. It was observed that minority of guinea fowl rearers took measures to protect the keets at night against temperature drop. Therefore, circadian rhythm of temperature represents an important cause of keet mortality. Kumar, in Pradu ${ }^{25}$ asserted that guinea fowls although hardy and resistant, are susceptible to viral diseases such as Newcastle, bacterial infections (E. coli), protozoan diseases (Coccidiosis) and verminous infestations (round worms). The author noted that Newcastle disease infestation is usually observed in a large flock of birds kept in confinement. Administration of Newcastle disease vaccine to the keets one week after hatching and repeating it at $8-10$ weeks of age, the author suggested may help in controlling the infection. E. coli is found to affect young keets of about 8-12 weeks of age. The infection is caused mainly due to poor litter management (damp flooring material). Sawdust which is the most common flooring material, during the rainy season becomes damp and wet leading to E. coli infections. Administering common antibiotics can control the infection. ${ }^{25}$ Unhygienic cage maintenance can cause Coccidiosis (severe diarrheal condition). The cage has to be cleaned regularly and kept dry to prevent this infection. Deworming birds every two months can effectively control roundworms infestation.

Difficulty in sexing of guinea fowls has been identified as one of the challenges to its production. ${ }^{10}$ According to Moreki ${ }^{18}$ sex determination in guinea fowl is extremely difficult especially in keets as males and females appear very similar to each other, thus making it difficult to distinguish them. The inability of the farmers to separate the sexes makes it difficult to raise a breeder or layers stock. It was reported that sometimes a whole stock intended for breeding turns up to be all males with a few females. Sex may be distinguished by the voice cry of the birds from about 8 weeks of age. The female make sounds like "buck-wheat, buck-wheat" or "put-rock, put-rock" which is quite different from the "wheat" sound of the males..$^{18}$ The wattles of the male have thicker edges at about 12-15 weeks of age. ${ }^{4}$ Umosen et al. ${ }^{26}$ reported that male guinea fowls carried their wattles cupped, that is, concave and carried at an acute angle to the side of the head. 


\section{Conclusion and recommendation}

It can be concluded that most of the problems faced with commercial production of guinea fowl in Nigeria is directly related to the system of management (free-range). It is therefore recommended that there is need to improve its management in terms of proper and adequate nutrition, efficient disease prevention and management, adequate housing as well as good management practices tailored to suit their natural behavior to ensure an optimum productivity in the guinea fowl enterprise.

\section{Acknowledgements}

None.

\section{Conflict of interest}

Author declares that there is no conflict of interest.

\section{References}

1. Ayorinde KL. The Spice of Life. Inaugural lecture, Nigeria: University of Ilorin; 2004.

2. Agwunobi LN, Ekpenyong TE. Nutritive and economic value of guinea fowl (Numida meleagris) production in developing countries. Journal of Science Food and Agriculture. 1990;52:301-308.

3. Oke UK, Ariwodo CA, Herbert U, et al. Impact of egg size on the fertility, hatchability and early growth traits of two varieties of guinea fowl in a humid tropical environment. Journal of Animal Science Advances. 2012;2(Suppl 3):299-305.

4. Ikani EI, Dafwang II. The Production of Guinea fowl in Nigeria. Extension Bulletin No. 207. Poultry Series No. 8. National Agricultural Extension and Research Liaison Services, Nigeria: Ahmadu Bello University; 2014:1-28.

5. FAO. Statistical database. Italy: Food and Agricultural Organization of United Nations; 1999.

6. Nwagu BI, Alawa CBI. Guinea fowl production in Nigeria. World Poultry Science Journal. 1995;(51):261 - 270

7. Obike OM, Oke UK, Azu KE. Comparison of egg quality traits of Pearl and Black varieties of guinea fowl in a Rain-Forest Zone of Nigeria. Nigeria: Proceedings of $36^{\text {th }}$ Conference of Nigerian Society for Animal Production, University of Abuja; 2011:19-21.

8. Naandam J, Issah GB. Hatchability of guinea fowl eggs and performance of keets under the traditional extensive system in Tolon- Kumbungu district of Ghana. Online Journal of Animal and Feed Research. 2012;2(3):253-257.

9. Moreki JC, Seabo D. Guinea fowl production in Botswana. Journal of World's Poultry Research. 2012;2(1):1-4.

10. Moreki JC, Radikara MV. Challenges to commercialization of guinea fowl in Africa. International Journal of Science and Research. 2013;2(11):436440 .

11. Dahouda M, Toleba SS, Youssao AKI, et al. Guinea fowl rearing constraints and flock composition under traditional management in Borgu depertment, Benin. Family Poultry. 2017;17(1):3-13.
12. Sayila A. Guinea fowl farming becomes popular in Botswana. World's Poultry. 2009;25(10):30-31.

13. Kusina NT, Saina H, Lebel S. An insight into guinea fowl rearing practices and productivity by guinea fowl keepers in Zimbabwe. African Journal of Agricultural Research. 2012;7(25):3521-3625.

14. Gono RK, Svinurai W, Muzvondiwa JV. Constraints and opportunities to guinea fowl production in Zimbabwe: A case study of the Midlands Province, Zimbabwe. International Journal of Science and Research. 2012;2(3):236-239.

15. Teye GA, Gyawu P. A guide to guinea fowl production in Ghana. Department of Animal Science, Ghana: University for Development studies; 2012.

16. Bankoungou GFX. Characteristics and performance of guinea fowl production under improved and scavenging conditions in Sahelian region of Burkina Faso. Master of Science Thesis, Denmar: The Royal Veterinary and Agricultural University; 2008.

17. Ocheja JO, Okpanachi U, Okpe AA, et al. Management problems of guinea fowl production in Nigeria. Nigeria: Proceedings $36^{\text {th }}$ Conference of Nigerian Society for Animal Production. University of Abuja; 2011:296-298.

18. Moreki JC. Guinea fowl Production. 2007.

19. Konlan SP, Avornyo FK. The effect of wetland on guinea fowl (Numida meleagris) egg productivity and fertility during the dry season in Guinea Savanna ecological zone of Ghana. Sky Journal of Agricultural Research. 2013;2(9):126-131.

20. Kebede H, Hussen DO, Melaku A. Study on status and constraints of village poultry production in Metema District, North- Western Ethiopia. American-Eurasian Journal of Scientific Research. 2012;7(6):246-251.

21. Boko CK, Kpodekon MT, Farougou S, et al. Farmer perceptions and pathological constraints in helmeted guinea fowl farming in the Borgu department in North East Benin. African Journal of Agricultural Research. 2011;6(10):2348-2357.

22. Ebegbulem VN. Growth, reproductive and genetic parameter estimates of the black and pearl guinea fowl (Numida meleagris) and their crosses. $\mathrm{PhD}$ thesis, Department of Animal Science, Nigeria: University of Calabar; 2016.

23. Moreki JC, Chiripasi SC, Montsho T, et al. Prevalence of poultry diseases and parasites in Botswana. Online Journal of Animal and Feed Research. 2011;1(5):130-134.

24. Harpreet S, Dash BB, Sanjeev K, et al. Mortality pattern in indigenous guinea fowl under confinement rearing. UK: Commonwealth Agricultural Bureau Abstracts; 1993.

25. Pradu MJ. Diseases of guinea fowl and their management. Farmers Note Book. 2005.

26. Umosen AD, Salami SO, Onyeanusi BI, et al. Use of wattle as a feature for sexing adult helmeted guinea fowl (Numida meleagris galleata). International Journal of Poultry Science. 2008;7(12):1204- 1206. 